\title{
Challenges in Using ICT in Teaching Secondary School Physics and Effect of Teaching Using ICT on Students' Physics Academic Achievement in Mombasa County, Kenya
}

\author{
Charles Mwambela $^{1 *} \quad$ Prof. Helen Mondoh ${ }^{1} \quad$ Prof. Thomas Thoruwa ${ }^{2}$ \\ 1. School of Education, Pwani University, P.O.Box 195-80108 Kilifi, Kenya \\ 2. School of Pure and Applied Sciences, Pwani University, P.O.Box 195-80108 Kilifi, Kenya
}

\begin{abstract}
In the recent past, the Government of Kenya and other stakeholders have invested massively in Information and Communication Technology (ICT) in secondary schools. The aim of this has been to enhance pedagogical approaches for teaching and learning. Information and Communication Technology (ICT) provides an opportunity for Educational Institutions and other organisations to harness and use technology to complement and support the teaching and learning process. However, despite the enormous advocacy for ICT-aided teaching and learning, investment and donation of ICT equipment to schools, there is a challenge of how to transform students learning process to provide students with the skills to function effectively in this information-rich and dynamic environment. This study was aimed at identifying the challenges involved in the use of ICT in the teaching of Physics and the possible solutions to the challenges Further, it sought to find the effect of using ICT on academic achievement of Secondary School Physics students in Mombasa County. This was done by administering questionnaires to 148 Physics teachers in public and private secondary schools, and conducting interviews with three (3) ICT champions in the county. An experiment was conducted involving 143 Form Two Physics students and one (1) Physics teacher in a purposively selected secondary school to determine the effect of teaching using ICT on students' academic achievement in Physics. The experimental data was analysed using a two way analysis of variance (ANOVA)., The finding of this study agree with Adeyemo who found that students performed better in Physics when ICT was applied in the teaching of Physics. Among the recommendations made was availing of better quality ICT resources to schools to improve learning outcomes.
\end{abstract}

DOI: $10.7176 / \mathrm{JEP} / 10-22-08$

Publication date: August $31^{\text {st }} 2019$

\section{Introduction}

The role of technology in teaching and learning is rapidly becoming one of the most important and widely discussed issues in contemporary Education Policies (Rosen \& Michelle, 1995; Thierer, 2000). Most experts in the field of Education agree that, when properly used, Information and Communication Technology (ICT) holds a great promise to improving teaching and learning and to shaping workforce opportunities. Poole, (1996) indicated that computer illiteracy is now regarded as the new illiteracy. Ofodu (2007) refers to Information and Communication Technology (ICT) as electronic or computerised devices, assisted by human and interactive materials that can be used for a wide range of teaching and learning as well as for personal use.

Improving school ICT facilities is essential in view of the current global revolution in teaching due to the changing nature of teachers' work, the realities of the information age, new global partnerships and awareness of technological changes (Feldner, 2003). Schools should therefore provide adequate ICT tools to enhance integration of ICT in teaching.

According to Kashorda, Waema, Omosa \& Kyalo, (2007), the introduction of ICT in education was part of the more fundamental objective to improve education globally and to make it accessible to everyone. They observed that the use of ICT in education had the potential to enhance the quality of teaching and learning, the research productivity of teachers and students, and the management and effectiveness of institutions.

ICT has the opportunity to revolutionise pedagogical methods, expand access to quality education and improve the management of education (World Bank, 2001). ICT is regarded as a critical tool for preparing and educating students with the required skills for the global work place (Ibe-Bassey, 2011).

According to Anthony (2012), the impact of ICT in education cannot be overemphasised. He noted that ICT solves problems concerning space and time. Accordingly, through ICT, the students can communicate, contact their teachers and collect and exchange information anywhere and anytime. Further, ICT also gives access to knowledge hence enabling the students to draw from a global pool of knowledge and also makes serving and sharing of knowledge easier. The students can therefore individually or together create records of notes and presentations which may help them to do better in their examinations. This way they are also trained for future participation in global research and communication. 


\subsection{Statement of the Problem}

According to research, in many countries, all the investments in ICT infrastructure, equipment and professional development to improve teaching have produced little evidence on improvement of students' academic performance. In Kenya, the scenario has not been different. Further, it is not also clear whether the various aspects of the ICT Integration Policy have been implemented as per guidelines. It is therefore necessary to find the missing link between such investment, policy and the students' academic achievement, and to identify and address any challenges involved. It was also necessary to establish experimentally whether integrating ICT in teaching had any positive effect on students' academic achievement.

\subsection{Research Questions}

The research aimed at answering the following six questions:-

1. What are the challenges faced in applying ICT in the teaching of Physics in Mombasa County ?

2. What are the possible solutions to the challenges in in the research question (3) above?

3. What is the effect of using ICT in the teaching of Physics on students' academic achievement in secondary school Physics?

\subsection{Research Hypothesis}

Ho. Students taught using ICT have a higher academic achievement in secondary school physics than those taught using traditional method.

\subsection{Literature Review}

2.1 Challenges in the use of ICT in teaching and learning

The process of integration of ICT in schools according to available empirical data faces several challenges. These include limited ICT facilities, costly Internet access, limited information sharing, limited skills for integration of ICT (Swarts and Wachira, 2010) and shortage of trained technicians (Mwalongo, 2011). Other challenges include limited electricity supply, poor telephone connectivity and inadequate number of computers (Smarkola, 2007). Hare (2007) considered lack of policy framework, inadequate infrastructure, high cost of bandwidth and inadequate in-service training of teachers on ICT in education as some of the factors inhibiting ICT integration.

According to Buabeng-Andoh (2012), one of the challenges in the use of ICT is the breakdown of computers causes interruption in the use of ICT in teaching and learning, If there is lack of technology assistance, then the regular repairs of computers will not be carried out resulting to teachers not using computers in teaching. Teachers will then be discouraged from using computers because of fear of equipment failure, since no one will give them technical support in case of technological problems.

\subsection{Effect of ICT on Learning Outcomes}

Acccording to Tedla (2012) Information and Communication Technology (ICT) creates a room to explore new things, provides a condusive climate for teaching-learning process to take place and also offers teachers the opportunity to play flexibility and enjoy effective ways of communication, collaboration, processing and solving of complex problems. This in turn, provides students the condition to develop their cognitive skills. He noted that the integration of ICT into classroom instructions, however, remains far behind because of several inhibiting factors, such as the inadequacy of infrastructures (internet access, bandwidth, software, hardware, computers), lack of realistic policy on ICT use, lack of teacher's pre-service and in-service training, poor teachers' welfare and morale, lack of parent and community participation, political and social conflict and tribal upheavals. Furthermore, it was realised that the importance of empirical research on the use of ICT is imperative in order to expose further inhibiting factors and in the meantime to promote training opportunities that are crucial towards learning process, teacher satisfaction and student achievement. A wise use of ICT, however, broadens teacher horizons, study and teaching flexibility and endorses wide access of learning and student participation (Tedla, 2012).

According to Makanda (2015), teaching using computer as a tool raises students' enthusiasm, interest and creativity. ICT use in teaching has effect on several teaching approaches such as collaborative learning and activity learning which have been associated with positive impact on learning outcome (Makanda,2015) According to Kamau (2014), the use of ICT in education improves teaching and learning at all levels of education.

\subsection{Research Methodology}

Two types of research design employed for this study. Descriptive Survey Study Design and Quasi-Experimental Design

\subsection{Descriptive Survey Study design}

According to Walliman (2011), descriptive survey deals with describing a phenomena or the state of something. It included gathering data related to products,people, individuals, events and situations, and analyzing it (Traverse, 
1978). The Descriptive Survey Study Design was employed in this study to define an opinion, attitude or behaviour held by Physics teachers on ICT integration in Physics Education. This was appropriate because the study involved collecting data in order to answer questions about the current status of ICT integration in the teaching of Physics in Secondary Schools in Mombasa County.

\subsection{Quasi-Experimental Design}

The Solomon's Four Group Design Model was used in this case. This model was preferred because it takes care of the effect of pre-test on the performance of the experimental group in the post-test (Campbell \& Stanley,1963). This model may be represented as shown in Figure 1.

\begin{tabular}{llll}
\hline Group & Pre-test & Treatment & Post-test \\
\hline $\mathrm{E}_{1}$ & $\mathrm{O}$ & $\mathrm{X}$ & $\mathrm{O}$ \\
$\mathrm{C}_{1}$ & $\mathrm{O}$ & & $\mathrm{O}$ \\
$\mathrm{E}_{2}$ & & $\mathrm{X}$ & $\mathrm{O}$ \\
$\mathrm{C}_{2}$ & & & $\mathrm{O}$ \\
\hline
\end{tabular}

Figure 1: Solomon's Four Group Design Model

Note: E: Experimental groups, C: Control groups, X: Treatment, O: Observation.

This design was used to investigate the effect of using ICT in teaching, on the academic achievement of Physics students as per the fifth objective of this study. It involved two experimental groups and two control groups. The treatment given to the experimental groups was teaching some concepts in the topic Electrostatics, using ICT, while the control groups were taught using the usual traditional instructional method which did not involve the use of ICT tools. This topic was preferred due to its abstract nature since the experiments involved in this topic do not work well in humid areas like Mombasa which is close to the ocean. Teaching the topic using ICT tools like video clips and animation would therefore be a good substitute for such experiments.

All the groups involved in the Quasi experiment were drawn from from Form Two Physics students from a purposively selected four-streamed school secondary school. These students were organised into four groups, according to their streams, two of which were Experimental groups $E_{1}$ and $E_{2}$, while the other two were Control groups $C_{1}$ and $C_{2}$. A pre-test and a post-test were administered before and after the treatment respectively to Experimental group $E_{1}$ and Control group $\left(C_{1} T\right.$ he Experimental group $E_{2}$, was given only a post-test after receiving treatment. The Control group $\mathrm{C}_{2}$; was only given the post-test after receiving treatment.

\subsection{Research Instruments}

3.3.1. Physics Teachers' Questionnaire, (PTQ)

This questionnaire had structured type items that sought information on the challenges faced by the teachers in using ICT facilities in teaching, and possible solutions to the challenges.

3.2.2. Pre-test for students-(PRETS)

This instrument was an achievement test designed by the researcher, to suit the level of the form two students. The pre-test had one section that consisted of 11 semi-structured type questions, carrying a total of 30 marks. Its duration was 45 minutes, This duration was appropriate since the test could be administered during after class preps to avoid interfering with other lessons. The questions were adopted from KCSE question papers between 2010 and 2016, whose language and concepts were simplified to suit the level of form two learners.

3.2.3 Post-test for Students (POSTS)

The post-test was also an achievement test designed by the researcher. It consisted of one section with 10 semistructured type questions and carried a total of 30 marks. Its duration was also 45 minutes. The questions were also adopted from the KCSE question papers between 2010 and 2016 and modified accordingly.

3.2.4 Interview Schedule for ICT Champions (ISIC)

This instrument was developed by the researcher based on the role of the ICT champions and the National ICT policy on Education. It had three sections. The first section had six items on personal information of the ICT champion. The second section had one item on challenges faced by ICT champions and solicited for qualitative data while the third section was about National ICT Policy on Education and solicited for information for both quantitative and qualitative data, The researcher administered the instrument in form of discussions with the ICT champions.

\subsection{Results, Interpretations and Discussions}

\subsection{Challenges faced in Teaching Physics using ICT Resources}

One of the tasks in this study was to identify the challenges faced by teachers in applying ICT in teaching Physics in Mombasa County. To identify the challenges, the required data was obtained from one item in section IV of the Physics Teachers Questionnaire (PTQ) and one item in section II of the Interview Schedule for ICT Champions (ISIC)) and the Checklist. The responses were grouped into eight themes according to Bryman's Four Stages of Qualitative analysis. The main themes for the challenges faced were: Inadequate resources; Inadequate space; 
Inadequate skills' Inadequate time; Lack of proper e-content; Unreliable power supply; Poor network coverage and Poor maintenance of ICT resources. The results are shown in Table 1.

Table 1 Challenges encountered in using ICT learning resources

\begin{tabular}{|c|c|c|c|c|c|}
\hline & & Frequency & Percent & Valid Percent & $\begin{array}{r}\text { Cumulative } \\
\text { Percent }\end{array}$ \\
\hline & Inadequate resources & 33 & 22.3 & 22.4 & 22.4 \\
\hline & Inadequate space & 7 & 4.7 & 4.8 & 27.2 \\
\hline & Inadequate skills & 25 & 16.9 & 17.0 & 44.2 \\
\hline & Inadequate time & 25 & 16.9 & 17.0 & 61.2 \\
\hline & Lack of proper e-content & 17 & 11.5 & 11.6 & 72.8 \\
\hline & Unreliable power & 18 & 12.2 & 12.2 & 85.0 \\
\hline & Poor internet coverage & 14 & 9.5 & 9.5 & 94.6 \\
\hline & Poor maintenance & 8 & 5.4 & 5.4 & 100.0 \\
\hline & Total & 147 & 99.3 & 100.0 & \\
\hline Missing & System & 1 & 0.7 & & \\
\hline Total & & 148 & 100.0 & & \\
\hline
\end{tabular}

Table 1 shows that out of the 147 challenges identified by the teachers, 33 of them (22.4\%) had to do with inadequate resources, 7 challenges $(4.8 \%)$ were about inadequate space for ICT lessons, $25(17.0 \%)$ were about lack of adequate skills, $25(17.0 \%)$ were about inadequate time for preparation of ICT lessons, 17(11.6\%) were about lack of proper e-content for ICT lessons, 18 (12.2\%) challenges were about unreliable power supply, 14 responses $(9.5 \%)$ had to do with poor internet coverage and eight responses were about poor maintenance of ICT resources. These results are represented using the bar chart in Figure 2.

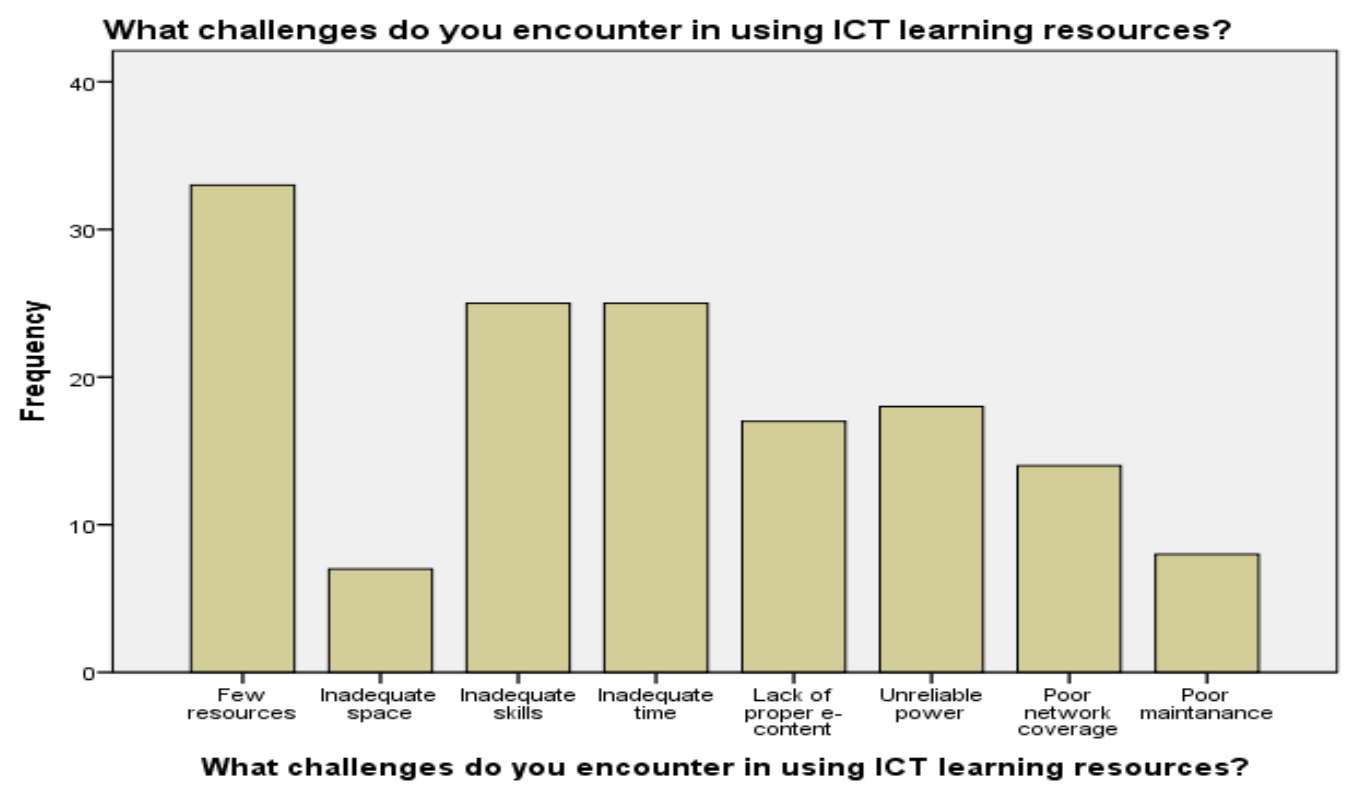

Figure 2: Challenges Encountered in Using ICT resources

The results show that the top in the list in terms of frequency were challenges to do with inadequate resources for ICT integration which were mentioned by 33 respondents. This was $22.4 \%$ of all the respondents to these items. Coming second at $17.0 \%$ were challenges to do with inadequate skills among the teachers in ICT integration and inadequate time for preparation for the ICT lessons. These challenges were mentioned by 25 respondents. Next in the list at $12.2 \%$ were challenges on unreliable electric power. This was mentioned by 18 respondents. Challenges on lack of proper e-content for use in class came next at $11.6 \%$. This was mentioned by 17 respondents. Poor internet coverage among the schools came next at $9.5 \%$ having been mentioned by 14 respondents. The other challenges were on poor maintenance of the ICT equipment and inadequate space for ICT lessons at $5.4 \%$ and $4.8 \%$ respectively.

From the interviews with the ICT champions, the following challenges were cited:

Old and dilapidated ICT equipment in schools, poor maintenance of the ICT tools, weak internet, lack of easy access of teachers' to school ICT facilities and lack of interest by some teachers who think training them is a waste of time. Other challenges include poor follow up of teachers' training on ICT due to lack of funds from the ministry of education for facilitation, lack of basic computer skills by teachers which are needed for training on ICT integration and substandard ICT equipment provided by the ministry of Education. 


\subsection{Possible Solutions to Challenges faced in Teaching Physics using ICT Resources}

To identify possible solutions to the challenges faced by teachers in applying ICT in the teaching of Physics in Mombasa County., the required data was obtained from one items in section IV of the Physics Teachers Questionnaire and one item in section II of the Interview Schedule for ICT Champions. The responses were grouped into eight themes according to Bryman's Four Stages of Qualitative analysis. The main themes for the possible solutions to the challenges faced were: Providing more ICT resources constructing well-furnished ICT labs; Proper maintenance of the available ICT resources; Reduction of teachers' workload; Training the teachers on integration of ICT in teaching; Having power backups in case of power failure; Providing stronger internet and the Availability of the e-content to be used in the ICT integrated lessons. The results are shown in Table 2. Table 2: Possible solutions to challenges in using ICT in teaching learning resources

\begin{tabular}{|llrrrr|}
\hline & Frequency & Percent & Valid Percent & Cumulative Percent \\
\hline \multirow{5}{*}{ Valid } & 37 & 25.0 & 27.2 & 27.2 \\
& Wore ICT resources & 11 & 7.4 & 8.1 & 35.3 \\
& Proper maintenance of ICT resources & 7 & 4.7 & 5.1 & 40.4 \\
& Less workload & 13 & 8.8 & 9.6 & 50.0 \\
& Training on ICT & 33 & 22.3 & 24.3 & 74.3 \\
& Ministry to provide proper e-content & 11 & 7.4 & 8.1 & 82.4 \\
& Total & 15 & 10.1 & 11.0 & 93.4 \\
& System & 9 & 6.1 & 6.6 & 100.0 \\
Missing & & 136 & 91.9 & 100.0 & \\
\hline Total & 12 & 8.1 & & \\
\hline
\end{tabular}

Table 2 shows that out of the 136 suggestions by Physics teachers for possible solutions to the challenges faced in teaching Physics, 37 suggestions (27.2\%) were about providing more ICT resources, 11 suggestions $(7.4 \%)$ were about constructing well-furnished ICT labs, seven suggestions (5.1\%) were about proper maintenance of the available ICT resources, 13 suggestions $(9.6 \%)$ were about reduction of teachers' workload, $33(24.3 \%)$ were about training the teachers on integration of ICT in teaching, $11(8.1 \%)$ were about having power backups in case of power failure, 15 responses $(11.0 \%)$ had to do with providing stronger internet and nine suggestions $(6.6 \%)$ were about the availability of the e-content to be used in the ICT integrated lessons. These results are represented using the bar chart in Figure 3.

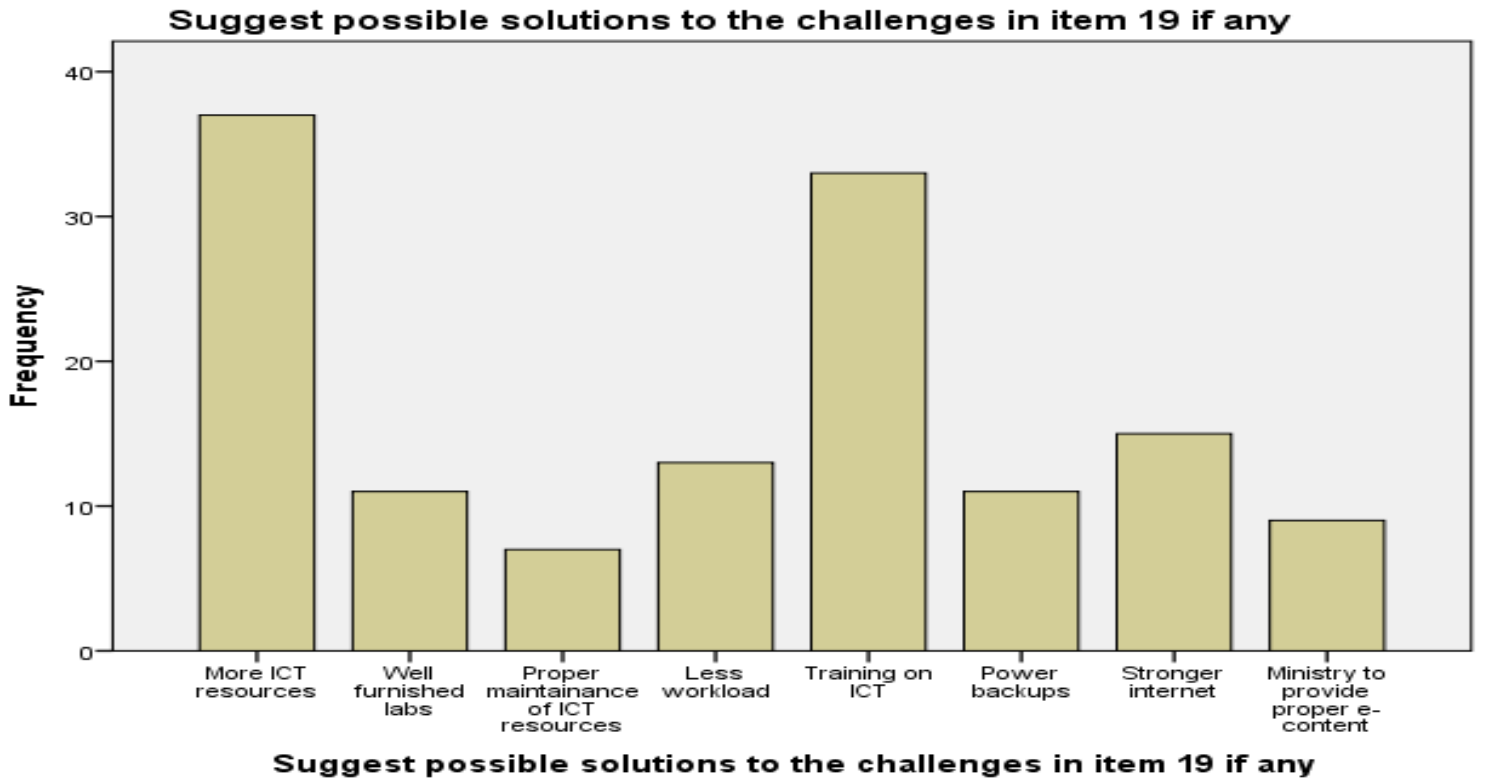

Figure 3: Possible solutions to the Challenges

Among the most highly recommended solutions in terms of the number of teachers who suggested them, are having more ICT resources, having more training on ICT, having stronger internet and having less teaching work load.

4.4 The effect of using ICT on students' Academic Achievement

The statistical treatment used in this case was the two way ANOVA where the first factor is whether the pre-test has been administered or not and the second factor is whether the treatment has been administered or not. The 
dependent variable is the students' score.

Table 3 shows the two-way ANOVA output of Tests of between subjects effects'

Dependent Variable: Students' scores

Table 3Tests of Between-Subjects Effects

\begin{tabular}{|c|c|c|c|c|c|c|}
\hline Source & Type III Sum of Squares & df & Mean Square & $\mathrm{F}$ & Sig. & Partial Eta Squared \\
\hline Corrected Model & $239.263^{\mathrm{a}}$ & 3 & 79.754 & 20.453 & .000 & .306 \\
\hline Intercept & 16808.303 & 1 & 16808.303 & 4310.537 & .000 & .969 \\
\hline Pretest & 150.726 & 1 & 150.726 & 38.654 & .000 & .218 \\
\hline Treatment & 86.272 & 1 & 86.272 & 22.125 & .000 & .137 \\
\hline Pretest $*$ Treatment & 1.276 & 1 & 1.276 & .327 & .568 & .002 \\
\hline Error & 542.010 & 139 & 3.899 & & & \\
\hline Total & 17517.000 & 143 & & & & \\
\hline Corrected Total & 781.273 & 142 & & & & \\
\hline
\end{tabular}

Table 3- shows the actual results of the two-way ANOVA- namely, whether either of the two independent variables or their interaction are statistically significant. From the table, the level of significance $p$ for the interaction between pretest and treatment was 0.568 .

\subsection{Summary, Conclusions and Recommendations}

\subsection{Summary}

Several challenges faced in integrating ICT in the teaching of Physics were cited by the Physics teachers, the biggest challenges being lack of adequate ICT resources, inadequate skills among the Physics teachers on how to handle ICT tools in teaching Physics and lack of adequate time for preparation of ICT integrated lesson.

To address these challenges, the respondents suggested that the government and the schools should find a way of adding more and better quality ICT resources in schools. They also suggested that teachers should also be more effectively trained on ICT through in-service training and at college level to increase their competence in the use of ICT tools in teaching. Other suggestions were strengthening network coverage in schools for easy access to online material and employment of more teachers among others.

On the effect of teaching using ICT on students' achievement in Physics, the two way ANOVA results show that both the pre-test and the treatment had a significant effect on the students score. The null hypothesis $\left(\mathrm{H}_{\mathrm{o}}\right)$ that students taught using ICT have a higher academic achievement than those taught using traditional method is therefore not rejected.

\subsection{Conclusion}

Among the challenges cited in the use of ICT in teaching were lack of adequate ICT resources, inadequate skills among the Physics teachers on how to handle ICT tools in teaching Physics, and lack of adequate time for preparation of ICT lessons. Inadequate time was due to high teaching loads for science teachers in a number of schools.

On the effect of teaching using ICT on students' academic achievement in Physics, the study reveals that using ICT in teaching enhances students' academic achievement. The use of ICT in teaching should therefore be facilitated and encouraged.

\subsection{Recommendations}

From the foregoing conclusion, it is clear that integration of ICT in teaching will enhance the achievement of Physics in secondary schools. The following recommendations were deemed appropriate for effective of ICT integration and effective use of ICT in the teaching of Physics.

i) Availing more ICT resources in schools required in the teaching of Physics. This can be done through funding or subsidising by the government. Schools should also allocate more funds for purchasing these resources. Teachers can also be encouraged to obtain their personal laptops and smart phones. This will help to sharpen their own skills in the use of ICT tools and to prepare their own e-content for use in their Physics lessons.

ii) The ICT resources should of good quality for more durability and low repair and maintenance costs

iii) More teachers should be employed by the government or school management to ease the teachers from high workloads. This will create more time for them to effectively plan their ICT integrated lessons.

iv) Teachers should be trained on ICT skills from the college level regardless of the subjects they specialise in. The training being done in insets like SMASSE and thorugh the ICT champions at school level should be intensified and followed up to ensure that the skills imparted are 
v) The ICT rooms should be designed to accommodate full classes without congestion. Power sockets and white walls as screens should also be availed in classrooms for ICT integrated lessons. This minimises competition for ICT rooms and computer labs.

vi) Schools should employ an ICT technician for proper maintenance and repairs of the ICT equipment. The technician will also help to induct the new teachers on the use of ICT tools.

vii) The Ministry of Education should supply adequate and relevant e-content for all topics for use in ICT integrated lessons since the schools may not be able to develop appropriate ones.

viii) There should be better maintenance of mains electricity power grid to minimise the frequent power failures experienced in our schools. Power generators should also be installed as a contingency measure in case of such power failures..

\section{References}

Anthony, O (2012). Challenges of effective use of ICT as a tool for implementing the UBE schemes 53rd annual conference of science teachers association of Nigeria 2012. HEBN publishers

Buabeng-Andoh C, 2012 Factors Influencing Teachers Adoption and Integration of ICT into teaching: A review of the Literature. International Journal of Education and Development usinf ICT 2012 Vol * Issue 1

Campbell, D. T., \& Stanley, J. C. (1966).Experimental and quasi-experimental designs Chicago, Rand McNally

Hare, H. (2007). Survey of ICT in Education in Burundi. Washington, DC:infoDev/World Bank.

Feldner, L. M. (2003). The Role of School Administrators in Supporting Teachers in the Integration of Education Technology into K-12 Classrooms. PhD thesis. North Dakota: University of North Dakota. Accessed Oct 28, 2006 from http://0- proquest.umi.com.oasis.unisa.ac.za:80/pqdweb?did

Ibe-Bassey, G.S (2011). Human capacity building for information and communication technology ICT integration in teacher education in Nigeria Association of educational media and technology (NAEMT).

Kamau L. M (2014), The Future of ICT in Kenyan Schools from a Historical Perspective: A Review of the Literature Journal of Education \& Human Development March 2014, Vol. 3, No. 1, pp. 105-118

Kashorda, M, Waema, T, Omosa, M \& Kyalo, V (2007) E-readiness Survey of Higher Education Institutions [accessed

10

Nov

2013] http://ereadiness.kenet.or.ke/sites/default/files/Ereadiness_survey_of_Kenyan_HigherEducation_June2007.

Makanda J. L (2015). Use of ICT in Teaching Physics: A case of Secondary Schools inKimilili District, Bungoma County ,Kenya.Unpublished

Mwalongo.A. (2011).Teachers' Perceptions about ICT for Teaching, Professional Development, Administration and Personal use. International Journal of Education and Development using information and Communication Technology (IJEDICT). 7 (3), p. 36-49.

Poole, G. A. (1996). A new gulf in American education, the digital divide. New York Times, January 29.

Rosen, L., \& Michelle, W. (1995).Computer availability, computer experience and technophobia among public school teachers. Computer in Human Behaviour, 11, 9-31.

Smarkola, C. (2007). Technology acceptance predictors among student teachers and experienced classroom teachers. Journal of Educational Computing Research, 31(1), 65-82. http://dx.doi.org/10.2190/J3GM-3RK12907-7U03

Swarts, P., and Wachira, M. E. (2010).: ICT in education Situational Analysis; Global e-Schools and Communities Initiative. pp 20-33

Thierer, A. (2000). Divided over the digital divide, Washington, DC:Heritage Foundation

Travers, R. (1978) Introduction to Educational Research (4 ${ }^{\text {th }}$ Edition) McMillan, London

Walliman, N. (2011) Research Methods: The basics. Routledge, London and NewYork

World Bank (2001).Information communication ties. A world bank group strategy, Washington D.C the world Bank group. 